\title{
SWAINSON'S HAWK LONGEVITY, COLOUR BANDING AND NATAL DISPERSAL
}

\author{
C. STUART HOUSTON, 863 University Drive, Saskatoon, SK S7N 0J8
}

I reviewed all banding records for North American Swainson's Hawks through the year 2000, and added 21 more recent encounters of Swainson's Hawks banded under my permit through 2003. I was interested in three topics: longevity (how long individuals live), where hawks spent the year after they hatched, and natal dispersal (movements from birth location to first breeding location) of Saskatchewan-born birds. Details of the 12 banded hawks that died from monocrotophos poisoning in Argentina are presented in a separate table and results of a colour banding experiment near Kindersley, SK in 1988-1995 are given special attention.

\section{History of Saskatchewan banding}

Saskatchewan is fortunate among all North American jurisdictions in having available banding data on the great majority of birds prior to computerization of banding records in 1955. All of the pre- 1955 recoveries and encounters of Saskatchewan birds have been computerized whereas North American banding data have been computerized retroactively only for game birds. ('Encounter' is the all-inclusive term that includes birds found dead or alive, whereas the term 'recovery' should be restricted to birds found dead.) Between 1924 and 1941, seven Saskatchewan banders banded 76 Swainson's Hawks, with the then-prevailing high rate of recoveries (14 or $18.4 \%$; 13 of the 14 had been shot) (Table 1). Hartley Fredeen of Macrorie, Saskatchewan, was the first North American bander to have a Swainson's Hawk recovered anywhere in South America, in Argentina on 23 December 1941. ${ }^{4}$ From 1955 to 2001, 13 Saskatchewan

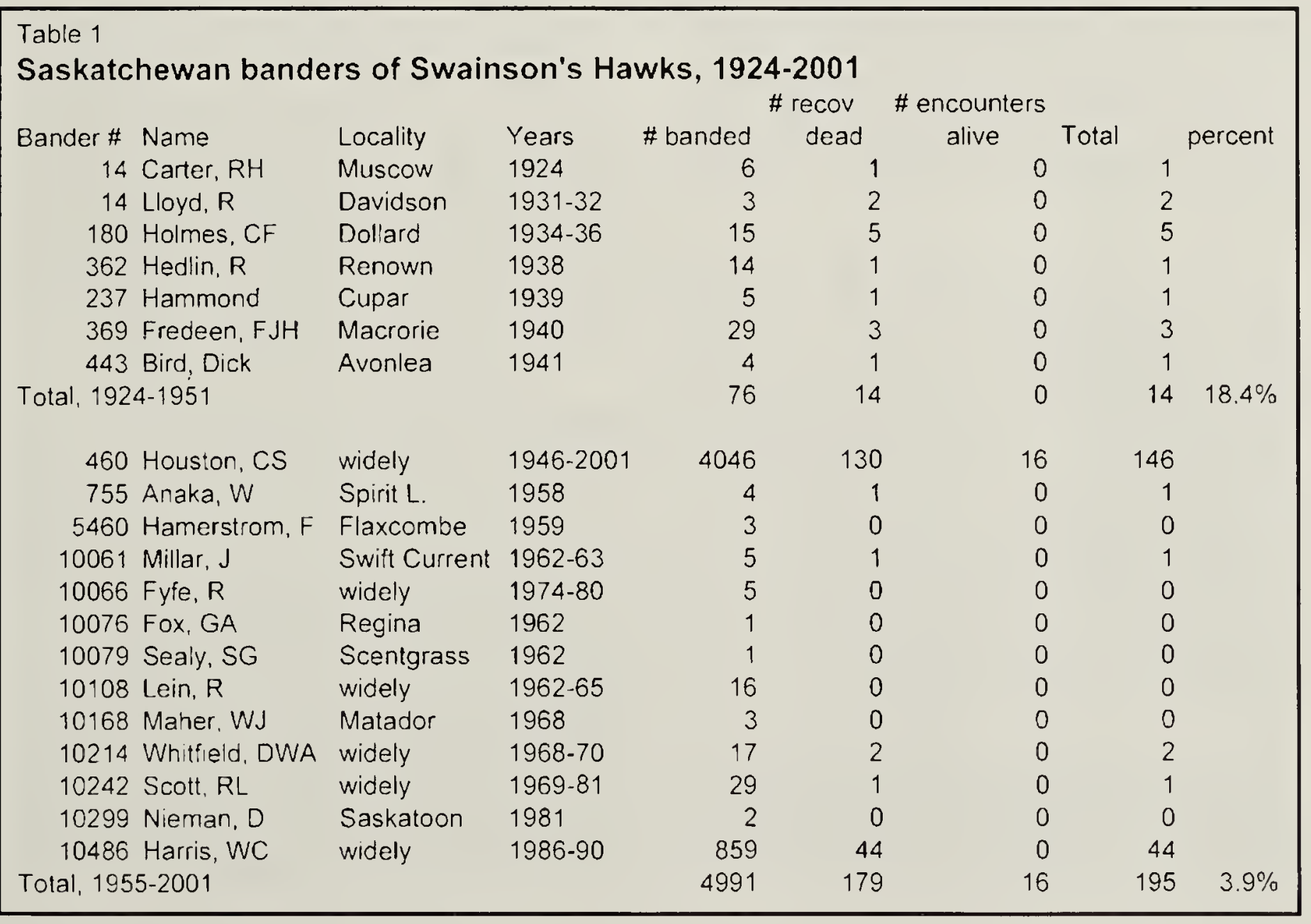


banders banded 4991 individual Swainson's Hawks with a recovery rate of dead hawks of $3.6 \%$ or, with inclusion of live birds, a total encounter rate of $3.9 \%$ (Table 1 ).

\section{Longevity}

Two recent Swainson's Hawk recoveries indicating unusually long survival led me to review all North American band encounters of this species. An earlier analysis of 550 encounters of 541 individual hawks banded in North America through 1992 had revealed that the four oldest birds had died at 13, 14, 15 and 18 years. $^{8}$

The Canadian Wildlife Service banding office provided an electronic record of the 762 encounters from North American banding through the year 2000 . The twelve banded Swainson's Hawks among the 1,690 that died from monocrotophos poisoning in La Pampa province of Argentina in January 1995 and January 1996 are part of this data set.

To increase the accuracy of the data from the hawks I had personally banded, I contacted most of the band finders by telephone or letter. Information from these people led to 32 changes in "how found" (four since the banding office printout mentioned above), and 19 corrections of latitude or longitude or both, in "where found."

Eight Swainson's Hawks in the banding office records are now known to have survived more than 17 years, one of which was still alive at last report (Table 2). Inclusion of live birds is at the suggestion of Brownie that sparse recaptures of live birds can be combined with recoveries of dead birds. ${ }^{2}$ The oldest hawk was one banded in Colorado and found dead of monocrotophos poisoning in Argentina at 19 years, 6 months.

The two hawks listed as alive in Table 2 are of special interest. One hawk had been banded by Joe Schmutz near Hanna, Alberta in 1975, and then trapped and released about $10 \mathrm{~km}$ distant in 1982, 1985 and 1986, where it had been resident in the same group of trees every year. In 1994, when 19 years old, it moved less than a kilometer to a new site, but in 1995 it was not seen and was presumed dead (J.K. Schmutz, pers. comm.). The second was a hawk banded at Lostwood Refuge, North Dakota, on July 14, 1983, by R.K. Murphy. On January 1, 2001, it was caught by hand, unable to fly, on an airport runway at Palmira, Colombia, only three degrees north of the equator. It was thought to have been poisoned from feeding in sugar cane fields nearby. It no doubt would have perished had it not been sent to a raptor rehabilitation facility operated by Luz-Stella Castillo. It was released after more than three months, able to fly, on April 16 (R.K. Murphy, pers. comm.).

At least one unreported encounter, not yet entered into the computerized central records, exceeds those within the system. Brian Woodbridge (pers.comm.) has had a 24-year-old hawk return alive to its breeding site in northern California, where it was trapped by Peter H. Bloom in 2004.

Details of all banded Swainson's Hawks recovered after the massive poisonings in Argentina are presented in Table 3. The 12 poisoned hawks are of special interest because of their high average age, and because five of the twelve originated in Saskatchewan and three in Alberta. Only incomplete details have been published previously. ${ }^{5}$

\section{Mortality of Saskatchewan-banded hawks}

There has not been a single undisputed recovery/encounter of a first year Swainson's Hawk banded in the area covered by the Kindersley 1:50,000 topographic map sheet (51 to 52 degrees latitude north and 108 to 110 degrees longitude west). To study this unexpected absence during the calendar year after hatching, when the hawks were 10 to 16 months old, before and just after 
蒙

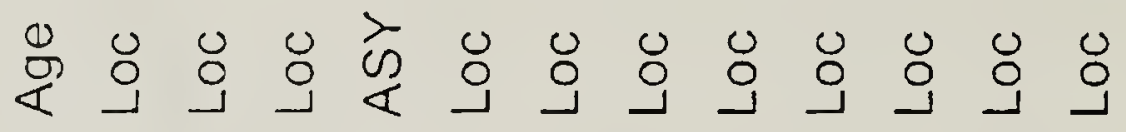

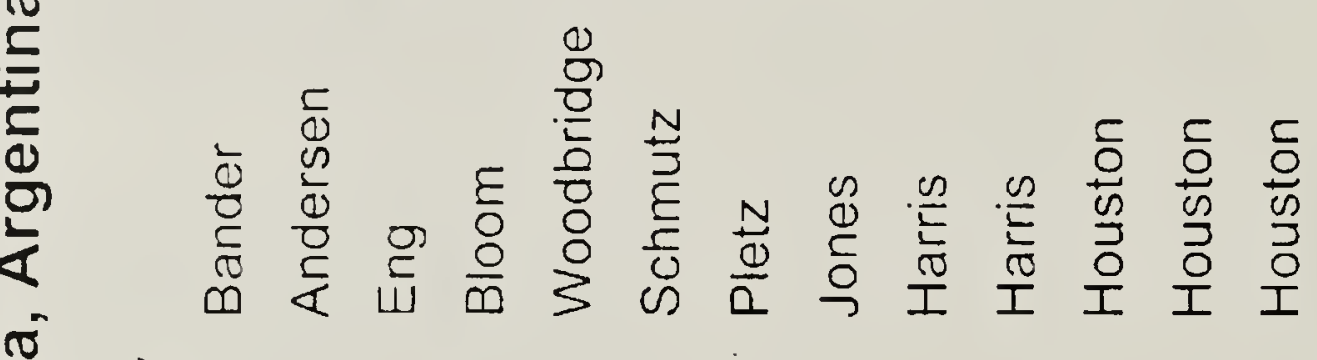

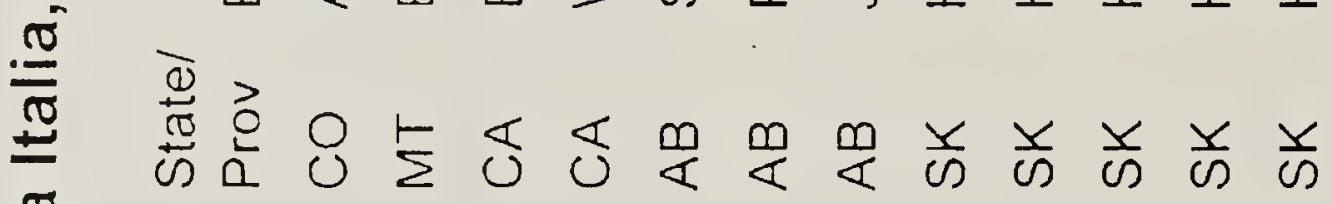

元

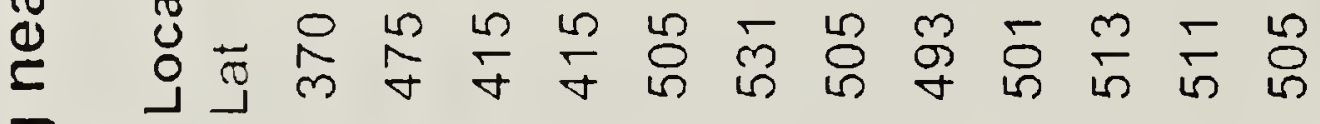

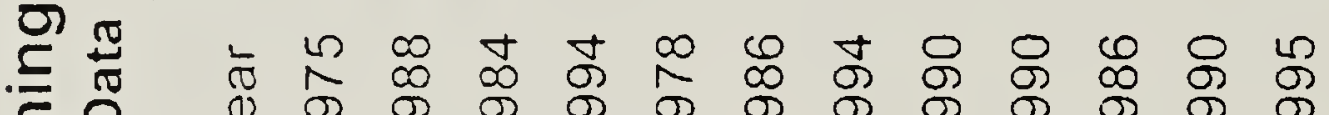

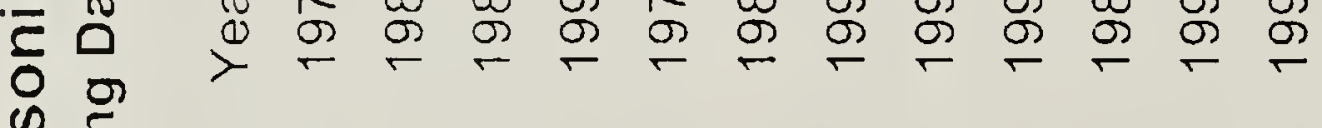

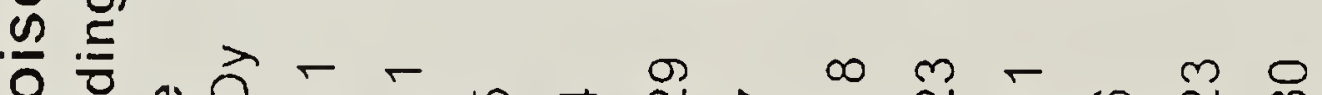

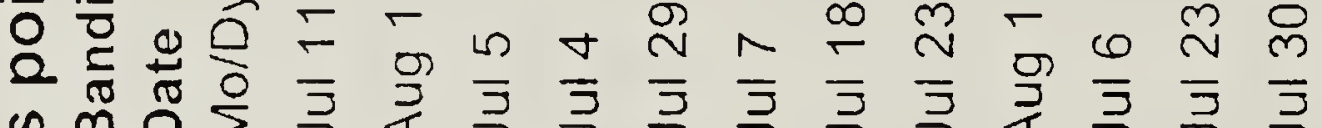

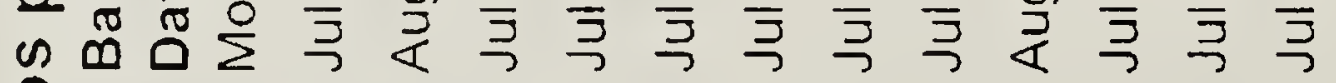

응

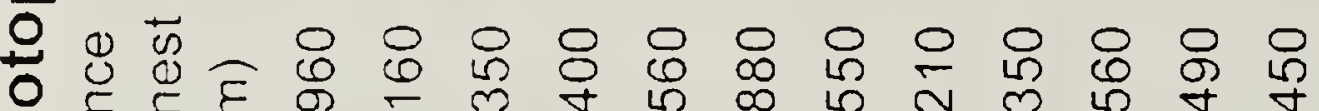

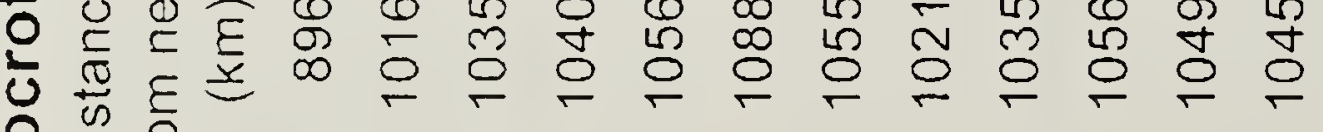

응

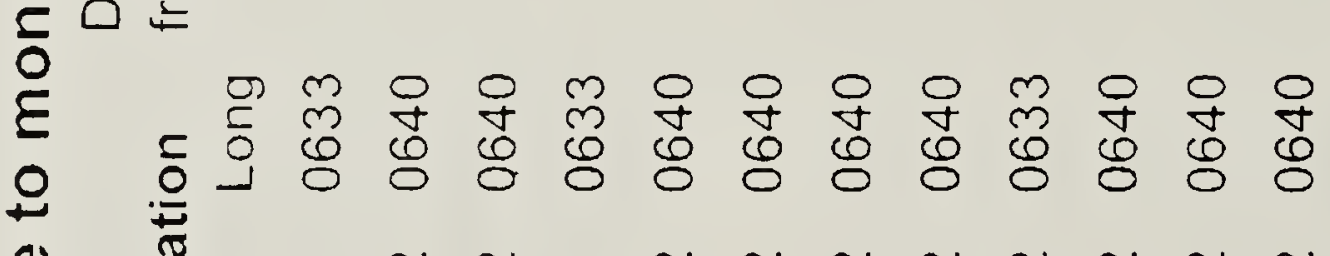

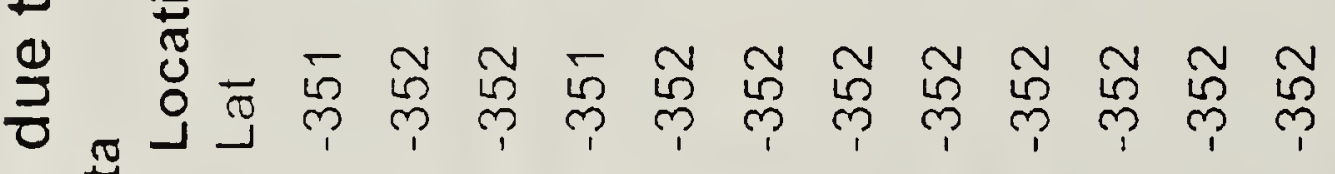

荡

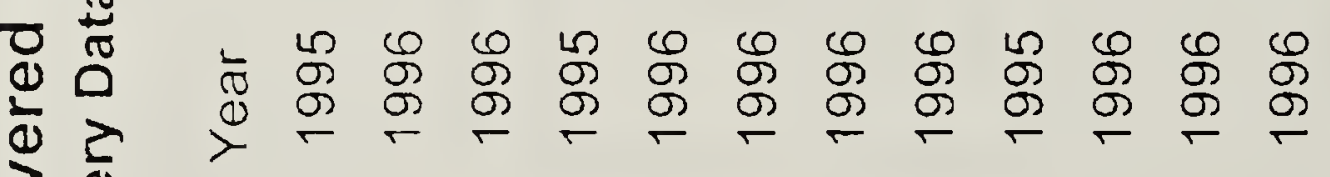

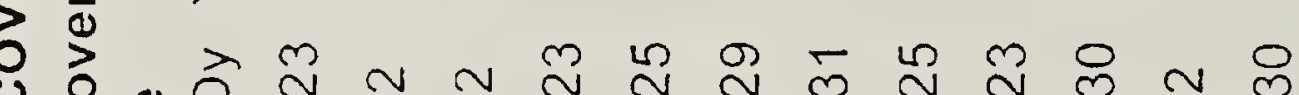

dי

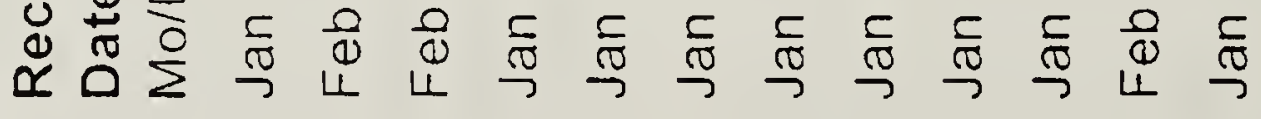

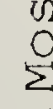

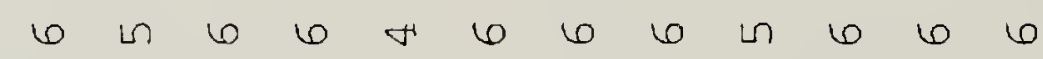

(1) थि क

$$
\text { i i i }
$$$$
>\text { मा मे }
$$

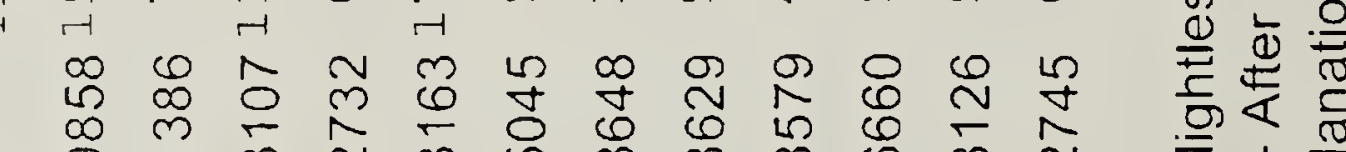

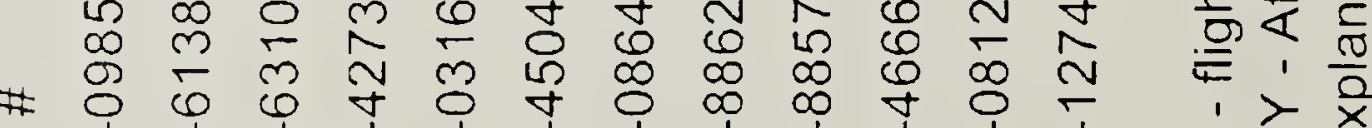

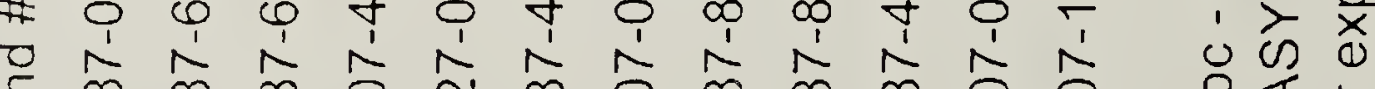

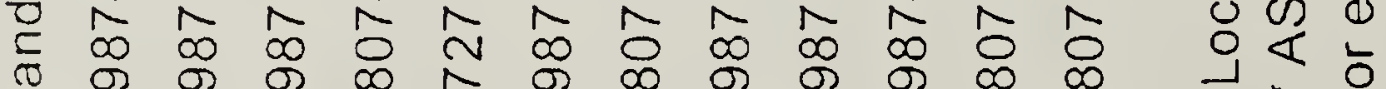

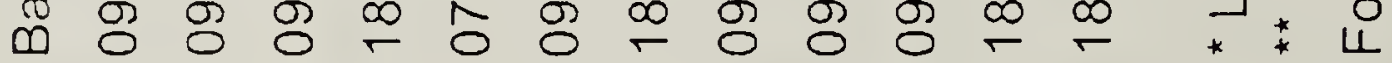


their first birthday, I compiled a life table based on all Saskatchewan banded Swainson's Hawks (Table 4). A life table shows the complete mortality data of a population, with respect to age, i.e. the age at which known deaths have occurred, and gives an idea of how long individual birds are likely to live. ${ }^{9}$

Some of the age categories in Table 4 require explanation. A recovery made in JulDec of the "calendar year of hatching" is what banders call a "direct recovery;" I have extended this to include the wintering area in Argentina, Paraguay and Uruguay through the end of March, when the birds are 9 months old. A recovery in Apr-Jun of the subsequent year leading up to July 1 when the bird is deemed to have had its first birthday, I have called "semidirect." Birds are classed as one year of age starting July 1 of the year after banding, but those encountered during the spring of the subsequent calendar year, when 21 to 23 months old, are ones that have made two trips to South America and back. These two categories of year-old birds have been separated in Table 4.

Five questionable records, initially within the age range of 9-12 months, were reassigned the status of "direct" recoveries in Table 4, for the following reasons. Reports of two different hawks, mailed in on March 23 and March 29, were dated before any Swainson's Hawks had returned, and must have originated from the banding year. A skeleton of a dead bird that had never left its nest was not reported until a year later. A band on a skeleton, found by a highway cleaning crew on April 5, clearly had been there all winter. A May 5 hawk leg with a band on it near a coyote den most probably dated from the previous year. The remaining April-June record was a letter posted on 17 April that failed to mention a date of finding; the band finder could not be contacted, and hence this record, the sole entry for the age category of 10-12 months, remains somewhat doubtful without a confrimed date of finding. The single Saskatchewan entry for 13-21 months was a hawk found fatally injured after its first birthday, within $10 \mathrm{~km}$ of its banding site, on August 31. The band finder could not be reached for confirmation.

With other species, in contrast with the banding results of Swainson's Hawk, the second-highest number in a life table is of birds in their second year of life. The other three "one-year-olds" were 22-24 months old before June 30 in the summer after their second trip to South America. Note the paucity of records for year-old hawks aged 13-24 months in Table 4, lower than for ages 2 and 3 years.

Nine-month-old Swainson's Hawks in their first journey back north from Argentina seem to lag behind mature birds, if one accepts the accuracy of band reporting dates. One such hawk was shot in Argentina on the late date of May 5, and another was behind schedule when it was shot in Colombia on an unspecified day in April. Similarly, individuals shot in Oklahoma and in South Dakota, both on May 10, and those found dead in Nebraska on June 1 and in South Dakota on an unspecified day in June, were unexpectedly far south for the date. These hawks would fit with my hypothesis that they were destined to spend their first 
summer somewhere south of where they had been raised the year before.

As is the case with all bird species studied to date, the peak of mortality is in the first nine months after banding, from July to March. But, in striking contrast to all other species I have studied, year-old Swainson's Hawks do not form the second largest number in the life table. This almost total lack of year-old birds returning to their breeding locality is similar to the experience of Woodbridge et al., who found a "virtual absence" of subadult hawks in their California study area. They suggested that "these birds spend their second summer elsewhere."14

The absence of year-old banded birds is supported by a lack of sightings of banded or unbanded first-year plumage birds in the Kindersley area. Some first-year Swainson's Hawks are presumed to show the very white plumage pictured in the extreme lower left figure on page 120 of Sibley as one of the three colour variations at this age, and in Brian Wheeler's plates, pages 291-292. ${ }^{12,13}$ Only in 2004 did we twice see the light plumage as far north as Bickleigh, southwest of Rosetown, Saskatchewan.

In striking contrast are the observations of Martin Bailey in a 110 by $13 \mathrm{~km}$ band of land paralleling highways 39 and 6 between Weyburn and Regina. ' Bailey has reported up to 200 hawks in this light-coloured plumage, presumptive year-old Swainson's Hawks, in late June and early July, 1997, suggesting that substantial numbers of nonbreeding hawks may return north only as far as extreme southern Saskatchewan. We hope others will be stimulated to watch for the light plumage of presumed year-old hawks, keeping track of locations and dates.

\section{Colour banding}

My eight-year colour banding project, begun in 1988 and restricted to the aforementioned Kindersley map sheet, had three objectives: to see if we could increase the number of band encounters by using a second band with an easily readable number; to learn whether or not Swainson's Hawks return to the approximate area where they were raised; and to learn where they spend their second calendar year. Swainson's Hawks are relatively tame, perch on poles and fenceposts and often allow a close approach. On such occasions it is possible to obtain a clear view of unfeathered tarsi.

I purchased anodysed alpha-numeric bands from A-Craft in Edmonton, each with one letter of the alphabet and one number in white on the colour background. These colour bands cost $\$ 4.70$ and $\$ 4.75$ each. In each instance, the numeral was on top and the letter below, repeated four times around the circumference of the band,

$\begin{array}{lllll}\text { e.g. } & 9 & 9 & 9 & 9 \\ & \text { D } & \text { D } & \text { D } & \text { D }\end{array}$

My helpers and I applied green bands to the left leg of 107 nestling Swainson's Hawks in 1988 and 93 to the right leg in 1989. Black bands were applied to the left leg of 128 hawks in 1990, and to the right leg of 97 in 1991 and 75 in 1992. Orange bands were applied to the right leg of 37 hawks in 1993, the right leg of 128 in 1994, and the left leg of 19 in 1995. Each nestling had a standard aluminum band applied to the other leg.

In each subsequent year, two or three weekends were spent in the Kindersley area in the last half of June, banding Ferruginous Hawk nestlings, and in the last half of July, banding Swainson's Hawk nestlings. During each of these visits, we scrutinized each perched Swainson's Hawk carefully. Some hawks did not sit still long enough for us to focus binoculars on the legs of the sitting bird, but others were close enough that at least the presence or absence of leg bands could be determined without doubt.

The Swainson's Hawk usually does not breed until at least three years of age. ${ }^{14} \mathrm{We}$ 
Table 5

RECOVERY RATES FOR SWAINSON'S HAWKS, 1988-1995

Encounters with aluminum and colour bands Encounters with aluminum bands only

\begin{tabular}{|c|c|c|c|c|}
\hline $\begin{array}{l}\text { Banding } \\
\text { Year }\end{array}$ & $\begin{array}{l}\text { Number } \\
\text { banded }\end{array}$ & $\begin{array}{c}\text { Number } \\
\text { encountered }\end{array}$ & $\begin{array}{l}\text { Number } \\
\text { banded }\end{array}$ & $\begin{array}{c}\text { Number } \\
\text { encountered }\end{array}$ \\
\hline 1988 & 107 & 1 & 56 & 1 \\
\hline 1989 & 93 & $4 *$ & 28 & 0 \\
\hline 1990 & 128 & 3 & 64 & 1 \\
\hline 1991 & 97 & 5 & 35 & 4 \\
\hline 1992 & 77 & 2 & 68 & 1 \\
\hline 1993 & 37 & 2 * & 20 & 0 \\
\hline 1994 & 128 & 1 & 46 & 2 \\
\hline 1995 & 17 & 1 & 104 & 4 \\
\hline Total & 684 & $\begin{array}{r}19 \\
2.8 \%\end{array}$ & 421 & $\begin{array}{r}13 \\
3.1 \%\end{array}$ \\
\hline
\end{tabular}

* another two each year were sighted near nest before achieving flight

fully expected that Swainson's Hawks would return to breed near their nest of origin at three or more years of age, and thus, beginning in 1991, we should have seen some breeding hawks with two bands, one aluminum and one coloured,

Throughout this study, we saw over 80 adult unbanded Swainson's Hawks each year, and counted our maximum number of unbanded adults, 102, during 1994. We sighted an aluminum band on two different hawks, but saw none with a colour band. Brian Woodbridge found no harmful effects from his long-term studies in northwestern California, where he sights or recaptures many birds each year, ${ }^{14}$ so I doubt that the second band was harmful in any way, for example by impeding prey capture.

Clearly, the addition of the readable colour band did not improve the band reporting rate. Only 23 of the 684 hawks colour-banded in these eight years were recovered elsewhere by band finders. This is a slightly smaller percentage than the number of encounters of birds with aluminum bands alone during the identical time period (Table 5).
We were therefore surprised when sightings of two of our colour bands were made at a distance.

A female nestling with green $4 \mathrm{~T}$ colour band applied near Mantario, Saskatchewan, on July 24, 1988, was sighted twice at its nest by Schmutz near Richdale, Alberta, on July 15, 1991 (presumably its first year of breeding), and on June 5, 1995. The other hawk with a colour band near a presumed nest site, banded as a male nestling with green 9A near Mantario on July 29, 1989 , was trapped and released by a falconer near Caronport, Saskatchewan, on June 4, 1998.

\section{Natal dispersal of Saskatchewan-banded hawks}

We next studied natal dispersal, the direction and distance of movement from the birth location to first breeding location (breeding dispersal refers to movements between successive breeding sites). ${ }^{5}$

To determine natal dispersal distances within Saskatchewan and Alberta, I restricted myself to evidence from 200 recoveries of dead birds and another 12 encounters of live 


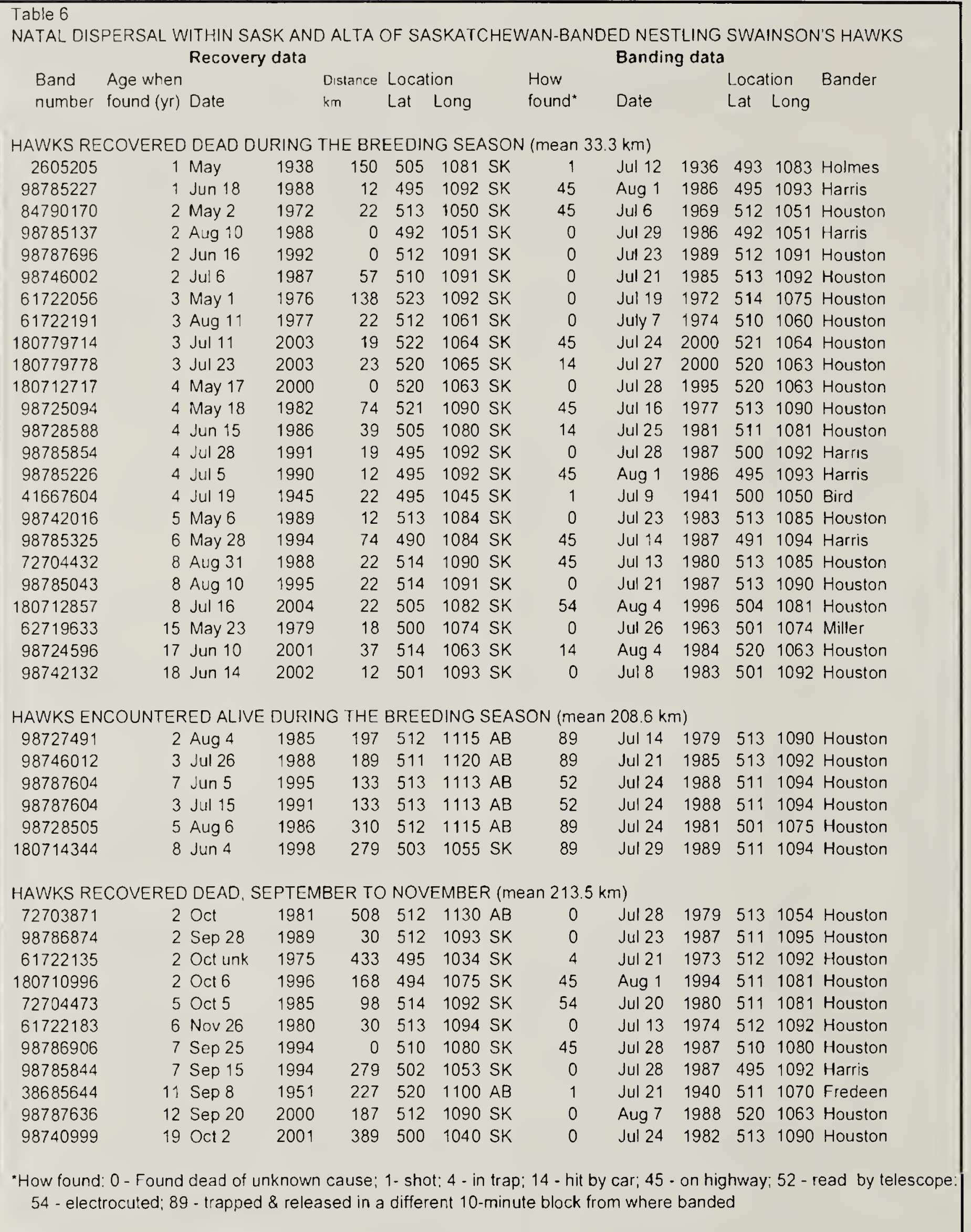

birds, including 21 reports of hawks received after the computer printout of hawks banded through 2001. I deleted encounters in the first 12 months and the 34 encounters in subsequent migrations beyond Canada. (The addition of my 2001-2003 data was acceptable only because I was the only Saskatchewan bander during the years of those late additions).
Distances between the birth site and the first breeding site were calculated from banding encounters of three types of birds within Saskatchewan and Alberta: those found dead during the breeding season (May to August) in subsequent years; those found alive during the breeding season; and those found dead within Saskatchewan during fall migration. This information is presented for 
each group, sorted by age (years after banding, with July 1 as the first day of each biological year), separately in Table 6 .

Mean distances from the nest where the hawk had been raised and its nest as an adult during the breeding season were $33.1 \mathrm{~km}$ for 23 hawks encountered dead and 206.8 $\mathrm{km}$ for six encountered alive. If we average these two breeding season groups by including six re-trapped or sighted alive at Hanna, Alberta and Caronport, Saskatchewan, the mean distance for all breeding season hawks is $66.7 \mathrm{~km}$.

If one could assume that the direction of dispersal from the natal area to the new breeding area is random (probably false because of habitat variability), and chose 67 $\mathrm{km}$ as a mean dispersal distance, then the area of the circle with a radius of this natal dispersal distance, gives us 14,108 square kilometers - an area sufficient for 1410 to 2820 Swainson's Hawk territories in good habitat assuming one to two pairs per $5 \mathrm{~km}^{2}$. These figures, similar to those for Great Horned Owls in Alberta and Saskatchewan, ${ }^{7}$ represent a conundrum. Simply and inexplicably, they do not "square" with our total absence of colour band sightings on and adjacent to the Kindersley map sheet area, at any age. If the absence of colour band sightings could be given credence, then one might postulate that the Kindersley area is a "source" of hawk breeding stock, rather than a "sink." 10 A net movement away from the Kindersley area by future breeders is supported by the overall population decline there."

1. BAILEY, M. 1998 Irruption of Swainson's hawks on the Regina plains. Western Birder [electronic, webbased journal, Bozeman, MT, now defunct].
2. BROWNIE, C., D.R. ANDERSON, K.P. BURNHAM, and D.S. ROBSON. 1985. Statistical inference from band recovery data: a handbook, 2nd ed. U.S. Fish \& Wildlife Service Resource Publ. 156.

3. CLARK, R.G., K.A. HOBSON, J.D. NICHOLS, S. BEARHOP. 2004. Avian dispersal and demography: scaling up to the landscape and beyond. Condor. 106:717-719.

4. COOKE, M.T. 1943. Returns from banded birds: some miscellaneous recoveries of interest. Bird-Banding 14:67-74.

5. GOLDSTEIN, B., B. WOODBRIDGE, M.E. ZACCAGNINI, and S.B. CANAVELLI. 1996. An assessment of mortality of Swainson's Hawks on wintering grounds in Argentina. J. Raptor Res. 30:106107.

6. GREENWOOD, P.J. 1980. Mating systems, philopatry and dispersal in birds and mammals. Anim. Behav. 28:1140-1162.

7. HOUSTON, C.S. 1999. Dispersal of Great Horned Owls banded in Saskatchewan and Alberta. J. Field Oinithol. 70:343-350.

8. HOUSTON, C.S., and J.K. SCHMUTZ. 1995. Swainson's Hawk banding in North America to 1992. North Am. Bird Bander 20:120-127.

9. LINCOLN, R.J., G.A. BOXSHALl, and P.F. CLARK. 1982. A Dictionary of Ecology, Evolution, and Systematics. Cambridge: Cambridge University Press.

10. PULliaM, H.R. 1988. Sources, sinks, and population regulation. American Natmalist 132:652661.

11. SCHMUTZ, J. K., C. S. HOUSTON and S. J. BARRY. 2001. Prey and reproduction in a metapopulation decline among Swainson's Hawks, Buteo swainsomi. Canadian Field-Naturalist 115 (2): 257-273

12. SIBLEY, D.A. 2000. The Sibley Guide to Birds. New York: Alfred A. Knopf, p. 120.

13. WHEELER, B.K. 2003. Raptors of Western North America. Princeton: Princeton University Press, plates 307 and 308, pages 291-292.

14. WOODBRIDGE, B., K.K. FINLEY and P.H. BLOOM. 1995. Reproductive performance, age structure, and natal dispersal of Swainson's Hawks in the Butte Valley, California. J. Raptor Res. 29:187-192. 